PNNL-14599, Rev. 0

\section{Pacific Northwest} National Laboratory

Operated by Battelle for the

U.S. Department of Energy

\title{
Atmospheric Data Package for the 2004 Composite Analysis
}

B. A. Napier

J. V. Ramsdell, Jr.

April 2004

Prepared for the U.S. Department of Energy under Contract DE-AC06-76RL01830 


\title{
DISCLAIMER
}

This report was prepared as an account of work sponsored by an agency of the United States Government. Neither the United States Government nor any agency thereof, nor Battelle Memorial Institute, nor any of their employees, makes any warranty, express or implied, or assumes any legal liability or responsibility for the accuracy, completeness, or usefulness of any information, apparatus, product, or process disclosed, or represents that its use would not infringe privately owned rights. Reference herein to any specific commercial product, process, or service by trade name, trademark, manufacturer, or otherwise does not necessarily constitute or imply its endorsement, recommendation, or favoring by the United States Government or any agency thereof, or Battelle Memorial Institute. The views and opinions of authors expressed herein do not necessarily state or reflect those of the United States Government or any agency thereof.

\author{
PACIFIC NORTHWEST NATIONAL LABORATORY \\ operated by \\ BATTELLE \\ for the \\ UNITED STATES DEPARTMENT OF ENERGY \\ under Contract DE-AC06-76RL01830
}

Printed in the United States of America
Available to DOE and DOE contractors from the Office of Scientific and Technical Information,
P.O. Box 62, Oak Ridge, TN 37831-0062;
ph: (865) 576-8401
fax: (865) 576-5728
email: reports@adonis.osti.gov

\author{
Available to the public from the National Technical Information Service, \\ U.S. Department of Commerce, 5285 Port Royal Rd., Springfield, VA 22161 \\ ph: (800) 553-6847 \\ fax: (703) 605-6900 \\ email: orders@ntis.fedworld.gov \\ online ordering: http://www.ntis.gov/ordering.htm
}

This document was printed on recycled paper. 


\title{
Atmospheric Data Package for the 2004 Composite Analysis
}

\author{
B. A. Napier \\ J. V. Ramsdell, Jr.
}

April 2004

Prepared for

the U.S. Department of Energy

under Contract DE-AC06-76RL01830

Pacific Northwest National Laboratory

Richland, Washington 99352 


\section{Summary}

A composite analysis is required by U.S. Department of Energy (DOE) Order 435.1 to ensure public safety through the management of active and planned low-level radioactive waste disposal facilities associated with the Hanford Site. The original Hanford Site Composite Analysis of 1998 must be revised and submitted to DOE Headquarters (DOE-HQ) in 2004 because of revisions to waste site information in the 100, 200, and 300 Areas, updated performance assessments and environmental impact statements (EIS), changes in inventory estimates for key sites and constituents, and a change in the definition of offsite receptors.

Beginning in fiscal year (FY) 2003, the DOE Richland Operations Office (DOE-RL) initiated activities, including the development of data packages, to support the 2004 Composite Analysis. This report describes the data compiled in FY2003 to support atmospheric modeling for the 2004 Composite Analysis. This work was conducted as part of the Characterization of Systems Task of the Groundwater Remediation Project (formerly the Groundwater Protection Program) managed by Fluor Hanford, Inc., Richland, Washington.

The purpose of this data package is to summarize our conceptual understanding of atmospheric transport and deposition, describe how this understanding will be simplified for numerical simulation as part of the 2004 Composite Analysis (i.e., implementation model), and finally to provide the input parameters needed for the simulations. 


\section{Contents}

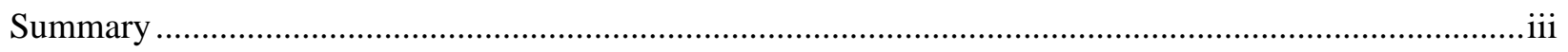

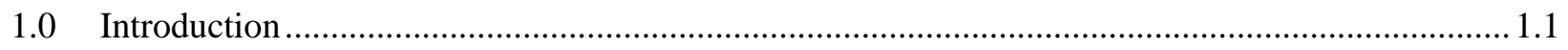

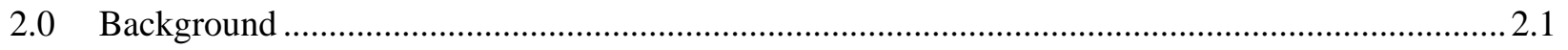

3.0 Theoretical Bases for Gaussian Models ....................................................................................... 3.1

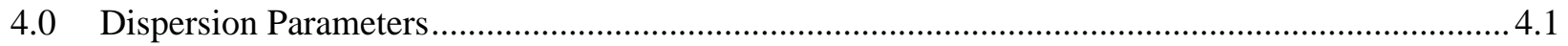

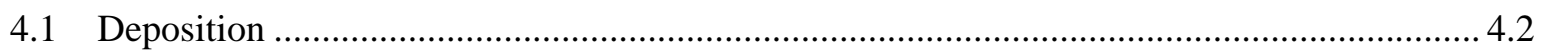

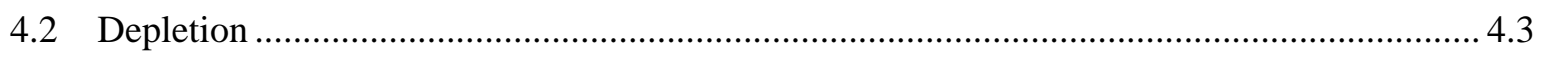

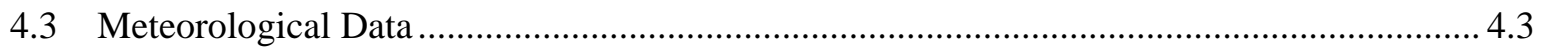

4.4 Calculating Spatially Varying Meteorological Conditions .............................................. 4.5

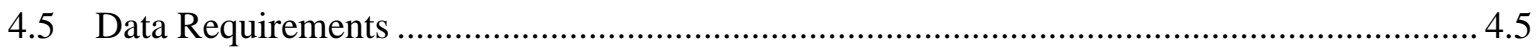

5.0 History Matching/Validation with Krypton-85 Monitoring Data .................................................. 5.1

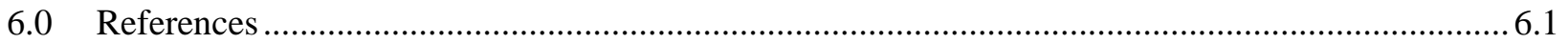




\section{Tables}

4.1 Constant Values for Calculation of Atmospheric Dispersion Parameters ...................................... 4.2

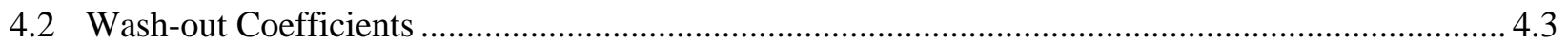

4.3 Atmospheric Transport Module Files ............................................................................................ 4.5

4.4 Details of Meteorological Stations Supplied to the Station File................................................... 4.7 


\subsection{Introduction}

A composite analysis is required by U.S. Department of Energy (DOE) Order 435.1 to ensure public safety through the management of active and planned low-level radioactive waste disposal facilities associated with the Hanford Site (DOE M 435.1-1). The original Composite Analysis detailed in Kincaid et al. (1998) must be revised and submitted to DOE Headquarters (DOE-HQ) in 2004 because of revisions to waste site information in the 100, 200, and 300 Areas, updated performance assessments and environmental impact statements (EIS), changes in inventory estimates for key sites and constituents, and a change in the definition of offsite receptors.

Kincaid, Bryce, and Buck (2004) describe the technical scope of the 2004 Composite Analysis for the Hanford Site and the approach to perform this analysis. It will be a site-wide analysis, considering final remedial actions for the Columbia River corridor and the Central Plateau, and will be a companion sitewide assessment to waste-specific and site-specific assessments. The 2004 Composite Analysis also will provide supporting information on a regional or site-wide basis for use in important Hanford assessments and decisions such as the CERCLA 5-year review in 2005, tank closure decisions, decisions on final groundwater remedies for the 200 Areas, decisions on final groundwater remedies for the 100 Areas, and the Columbia River corridor final record of decision.

Beginning in fiscal year (FY) 2003, the DOE Richland Operations Office (DOE-RL) initiated activities, including the development of data packages, to support the 2004 Composite Analysis. This report describes the data compiled in FY2003 to support atmospheric modeling for the 2004 Composite Analysis. This work was conducted as part of the Characterization of Systems Task of the Groundwater Remediation Project (formerly the Groundwater Protection Program) managed by Fluor Hanford, Inc., Richland, Washington.

The purpose of this data package is to summarize our conceptual understanding of atmospheric transport and deposition, describe how this understanding will be simplified for numerical simulation as part of the 2004 Composite Analysis (i.e., implementation model), and finally to provide the input parameters needed for the simulations.

The general approach for this work was to extract data and interpreted information from existing documents and databases. Every attempt was made to provide traceability back to the original source(s)

of the data or interpretations. 


\subsection{Background}

The atmospheric transport and deposition model selected for implementation in the System Assessment Capability (SAC Rev. 1) is named RATCHET (Ramsdell et al. 1994). An adaptation of RATCHET, named RATCHET2, was prepared.

RATCHET2 is a Lagrangian trajectory, Gaussian puff atmospheric dispersion model that includes deposition and depletion. The code was originally developed for the Hanford Environmental Dose Reconstruction Project (HEDR). For HEDR, it used hourly meteorological and iodine-131 release data to estimate daily exposures (time-integrated concentrations) and surface contamination over an area of approximately 195,000 $\mathrm{km}^{2}$ (75,000 $\left.\mathrm{mi}^{2}\right)$ in eastern Washington, eastern Oregon, and northern Idaho. For SAC, RATCHET2 has been modified to estimate normalized annual exposures and surface contamination over an area of approximately $9,100 \mathrm{~km}^{2}\left(3,500 \mathrm{mi}^{2}\right)$ that includes the Hanford Site and adjacent land. Meteorological data for the SAC Rev. 1 calculations consist of hourly observations made at 28 stations from 1983 through 2003. These data, which typically include wind direction and speed, temperature, precipitation, and an indicator of atmospheric stability, are used to derive the spatially and temporally varying meteorological fields needed by RATCHET2. Ground-level and elevated release points can be placed at appropriate locations on the Hanford Site, and exposures and surface contamination are estimated at more than 2100 locations on a 41 x 53 Cartesian grid that has $2 \mathrm{~km}$ spacing.

Gaussian models are used to describe the atmospheric dispersion of radioactive and chemical effluents from nuclear facilities. These models have frequently been used in licensing and emergency response calculations [e.g., PAVAN (Bander 1982), XOQDOQ (Sagendorf et al. 1982), MESORAD (Scherpelz et al.1986; Ramsdell et al. 1988), and RASCAL Version 2.0 (Athey et al. 1993; McGuire et al. 2003)], because they quickly provide reasonable estimates of atmospheric concentrations, deposition, and doses given relatively limited information on topography and meteorology. A Lagrangian-trajectory Gaussian puff model is used where temporal or spatial variations in meteorological conditions or depletion of the plume due to dry deposition may be significant. 


\subsection{Theoretical Bases for Gaussian Models}

The derivation of the Gaussian models used to describe atmospheric dispersion is discussed in many texts. Various texts including Slade (1968), Csanady (1973), Randerson (1984), and Seinfeld (1986) provide the bases for the following discussion. They may be consulted where additional detail is desired.

Atmospheric dispersion is governed, in part, by a differential equation called the diffusion equation. With a set of assumptions that can reasonably be applied to atmospheric processes, the diffusion equation has a specific, closed-form algebraic solution that is Gaussian. In one dimension, the solution is

$$
\chi(\mathrm{x}) / \mathrm{Q}=\frac{1}{(2 \pi)^{1 / 2} \sigma} \exp \left[-\frac{1}{2}\left(\frac{\mathrm{x}-\mathrm{x}_{\mathrm{o}}}{\sigma}\right)^{2}\right]
$$

where $\chi(\mathrm{x})=$ concentration at a distance $\mathrm{x}$ from the center of the concentration distribution, $\mathrm{x}_{\mathrm{o}}$

$\mathrm{Q}=$ amount of material released

$\sigma=$ dispersion parameter

Atmospheric dispersion parameters are functions of either distance from the release point or time since release. They may also be functions of atmospheric stability and surface roughness. Numerous atmospheric dispersion experiments have been conducted to evaluate dispersion parameters and to develop methods to predict dispersion-parameter values from readily available data. A number of these experiments are described by Draxler (1984).

The one-dimensional solution of the diffusion equation can be expanded to three dimensions using the principle of superposition to get the basic Gaussian puff model. In a Cartesian coordinate system with $\mathrm{x}$ and $\mathrm{y}$ axes in a horizontal plane and $\mathrm{z}$ in the vertical, the normalized concentration in the vicinity of the puff is

$$
\chi(\mathrm{x}, \mathrm{y}, \mathrm{z}) / \mathrm{Q}=\frac{1}{(2 \pi)^{3 / 2} \sigma_{\mathrm{x}} \sigma_{\mathrm{y}} \sigma_{2}} \exp \left[-\frac{1}{2}\left(\frac{\mathrm{x}-\mathrm{x}_{\mathrm{o}}}{\sigma_{2}}\right)^{2}\right] \exp \left[-\frac{1}{2}\left(\frac{\mathrm{y}-\mathrm{y}_{\mathrm{o}}}{\sigma_{\mathrm{y}}}\right)^{2}\right] \exp \left[-\frac{1}{2}\left(\frac{\mathrm{z}-\mathrm{z}_{\mathrm{o}}}{\sigma_{\mathrm{z}}}\right)^{2}\right]
$$

This equation, when combined with a transport mechanism to move the center of the puff $\left(\mathrm{x}_{0}, \mathrm{y}_{0}, \mathrm{z}_{0}\right)$, is a simplified version of the puff model in RATCHET2. The dispersion parameters are shown as functions of direction from the puff center. However, in most implementations of the puff model, the puff is assumed to be symmetrical in the $\mathrm{x}$ and $\mathrm{y}$ directions. Hence, $\mathrm{x}$ and $\mathrm{y}$ may be replaced by the horizontal distance $r$ from the center of the puff.

The form of Eq. (3.1) shown is appropriate if the height of the center of the puff is such that vertical dispersion proceeds unimpeded either by the ground or by an elevated layer of the atmosphere.

Unimpeded vertical dispersion is generally not the case. Typically, the earth's surface and the top of the atmospheric mixing layer are assumed to be reflective surfaces. When these assumptions are made, the vertical exponential term 


$$
\exp \left[-\frac{1}{2}\left(\frac{\mathrm{z}-\mathrm{z}_{\mathrm{o}}}{\sigma_{\mathrm{z}}}\right)^{2}\right]
$$

is replaced by a sum of exponential terms that account for reflection. This sum is

$$
\sum_{n=-\infty}^{\infty}\left\{\exp \left[-\frac{1}{2}\left(\frac{2 n H-h-z}{\sigma_{2}}\right)\right]^{2}+\exp \left[-\frac{1}{2}\left(\frac{2 n H+h-z}{\sigma_{2}}\right)\right]^{2}\right\}
$$

where $\mathrm{H}=$ the height of the top of the mixing layer

$\mathrm{h}=$ the release height

In practice, only a small number of terms need be considered. In RATCHET2, as in MESORAD (Scherpelz et al. 1986; Ramsdell et al. 1988) and RASCAL (McGuire et al. 2003), the summation is carried out from $n=-2$ to 2 . This term can be simplified if one or more of $\mathrm{H}, \mathrm{h}$, or $\mathrm{z}$ equals zero. For example if $\mathrm{H}$ is large compared to $\sigma_{\mathrm{z}}$ and $\mathrm{z}$ is zero, the summation may be replaced by

$$
2 \exp \left[-\frac{1}{2}\left(\frac{\mathrm{h}}{\sigma_{2}}\right)^{2}\right]
$$

At long down-wind distances where the vertical dispersion parameter is the same magnitude as the mixing layer thickness, the puff model can be further simplified by assuming that material is uniformly distributed in the vertical. With this last assumption, the puff model becomes

$$
\chi(\mathrm{r}) / \mathrm{Q}=\frac{1}{2 \pi \sigma_{\mathrm{r}}^{2} \mathrm{H}} \exp \left[-\frac{1}{2}\left(\frac{\mathrm{r}}{\sigma_{\mathrm{r}}}\right)^{2}\right]
$$

where $\mathrm{H}$ is the mixing layer thickness. RATCHET2 switches to the uniformly mixed model when $\sigma_{\mathrm{z}}>$ $1.05 \mathrm{H}$.

The Gaussian puff model behaves well in calm winds. If the dispersion parameters are a function of time, as they are in many models, the material in the puff continues to disperse even though it isn't moving. If, as in RATCHET2, the dispersion parameters are calculated as the function of travel distance, dispersion ceases during calm winds, and the material distribution remains unchanged as long as the wind is calm. In either case, deposition, depletion, exposures, and doses are calculated just as they are during windy conditions.

The calculational domain consists of a square Cartesian grid with receptor nodes uniformly spaced throughout the domain. 
RATCHET2 explicitly accounts for transit time in all calculations because the model tracks the movement of individual puffs and calculates concentrations and doses based on puff positions. Decay and ingrowth of radionuclides and depletion of the puffs as a result of wet and dry deposition are calculated at 5-minute intervals.

Neither the wind data nor the wind fields are modified to force the centers of puffs to pass directly over the receptor nodes. As time goes by and atmospheric conditions (wind direction, wind speed, stability, mixing layer thickness, and precipitation) change, Gaussian puff models will give realistic concentration and dose patterns. In addition, puff models will give more realistic concentration and dose patterns than plume models when topography modifies the winds because the wind fields may be modified to account for topography.

The movement of puffs is controlled by the wind at the center of the puff as it moves through the model domain. The spatial variation of winds is represented by two-dimensional fields of vectors that give the direction and speed of puff movement. These fields are prepared by the meteorological model and are updated at 15-minute intervals based on the available wind data.

Calculation of puff movement is a six-step process. In sequence, the steps are

1. Make an initial estimate of the direction and speed of the puff movement given the current puff position and height above ground using bilinear interpolation (Press et al. 1986) of the vectors at the nearest nodes of the field.

2. Make an initial estimate of the puff position at the end of the period using the initial estimates of direction and speed.

3. Make a second estimate of the direction and speed of puff movement using the estimated puff position at the end of the period.

4. Make a second estimate of the puff position at the end of the period using the estimate of direction and speed from Step 3.

5. Average the end points calculated in Steps 2 and 4.

6. Calculate the final estimate of direction and speed of puff movement using the puff's initial position and the average end point calculated in Step 5.

The actual puff movement for the period may take place in one or several steps. The step size is adjusted to ensure adequate accuracy in the integration of concentrations that takes place at receptors. Errors in the integration should be less than 5\% at typical wind speeds.

The vector fields prepared by the meteorological program are for a height of $10 \mathrm{~m}$ above ground. These vectors are used for puffs that represent ground-level releases. If the actual release height is greater than $12 \mathrm{~m}$, a wind-speed profile is used to adjust the transport speed from $10 \mathrm{~m}$ to the puff transport height. The profile used to adjust the wind speed considers both surface friction and atmospheric stability (see Panofsky and Dutton 1984, Sections 6.4 and 6.6). 


\subsection{Dispersion Parameters}

The horizontal dispersion parameters $\left(\sigma_{\mathrm{y}}\right.$ and $\sigma_{\mathrm{r}}$ ) used in the dispersion model are based on the results of a large number of dispersion experiments conducted in the 1950s and 1960s. The experiments, which were conducted over relatively flat terrain, typically involved tracer releases ranging from about 10 minutes to 1 hour in duration with ground-level concentration measurements at distances ranging from $100 \mathrm{~m}$ to several kilometers. Only a few direct measurements of vertical dispersion parameters $\left(\sigma_{\mathrm{z}}\right)$ were made. Consequently, vertical dispersion parameters have been estimated with dispersion models using measured values of the horizontal dispersion parameter and measured concentrations. Dispersion parameters have been summarized in many forms. Perhaps the best known summary is the set of dispersion parameter curves called the Pasquill and Gifford curves (Gifford 1976).

Regulatory guidance published by the U.S. Nuclear Regulatory Commission (NRC) includes graphic depiction of these curves, and numerical approximations to the curves are included in many computer codes used by the NRC. In RATCHET2, dispersion parameters are estimated using the same basic algorithms that were used in RASCAL (McGuire et al. 2003) and are used in other NRC codes including PAVAN (Bander 1982) and XOQDOQ (Sagendorf et al. 1982). These parameterizations have generally been attributed to Eimutis and Konicek (1972). However, the $\sigma_{\mathrm{y}}$ parameterization is properly attributed to Tadmor and Gur (1969), and the $\sigma_{z}$ parameterization is properly attributed to Martin and Tikvart (1968).

The basic dispersion parameter relationships are

$$
\sigma_{y}(x)=a_{y} x^{0.9031}
$$

and

$$
\sigma_{z}(x)=a_{z}(x) \cdot x^{b_{z}(x)}+c_{z}(x)
$$

where $\quad \mathrm{x}=$ the distance from the release point, in meters

$\mathrm{a}_{\mathrm{y}}=\mathrm{a}$ function of stability class

$\mathrm{a}_{\mathrm{z}}, \mathrm{b}_{\mathrm{z}}$, and $\mathrm{c}_{\mathrm{z}}=$ functions of stability class and distance

Table 4.1 gives values for $\mathrm{a}_{\mathrm{y}}, \mathrm{a}_{\mathrm{z}}, \mathrm{b}_{\mathrm{z}}$, and $\mathrm{c}_{\mathrm{z}}$. Note that $0.9031, \mathrm{a}_{\mathrm{y}}, \mathrm{a}_{\mathrm{z}}, \mathrm{b}_{\mathrm{z}}$ and $\mathrm{c}_{\mathrm{z}}$ are empirical constants evaluated by fitting curves. Of these constants, 0.9031 and $b_{z}$ are dimensionless; $c_{z}$ has dimensions of meters; and $\mathrm{a}_{\mathrm{y}}$ and $\mathrm{a}_{\mathrm{z}}$ have dimensions of $m^{(1.0-0.9031)}$ and $m^{\left(1-b_{\mathrm{x}}\right)}$, respectively.

The mixing layer thickness is included in all dispersion calculations. The thickness is passed to the atmospheric dispersion program in the meteorological data files. The thickness may be estimated from meteorological data and surface roughness; it may be estimated from climatological data; or it may be entered directly. 
Table 4.1. Constant Values for Calculation of Atmospheric Dispersion Parameters

\begin{tabular}{|c|c|c|c|c|c|c|c|c|}
\hline & \multirow[b]{2}{*}{ Distance Range (m) } & \multicolumn{7}{|c|}{ Stability Class } \\
\hline & & A & B & $\mathrm{C}$ & $\mathrm{D}$ & $\mathrm{E}$ & $\mathrm{F}$ & G \\
\hline$\overline{a_{y}}$ & all $x$ & 0.3658 & 0.2751 & 0.2089 & 0.1471 & 0.1046 & 0.0722 & 0.0481 \\
\hline \multirow[t]{3}{*}{$\mathrm{a}_{\mathrm{z}}$} & $\mathrm{x}<100 \mathrm{~m}$ & 0.192 & 0.156 & 0.116 & 0.079 & 0.063 & 0.053 & 0.032 \\
\hline & $100 \mathrm{~m}<\mathrm{x}<1000 \mathrm{~m}$ & 0.00066 & 0.0382 & 0.113 & 0.222 & 0.211 & 0.086 & 0.052 \\
\hline & $1000 \mathrm{~m}<\mathrm{x}$ & 0.00024 & 0.055 & 0.113 & 1.26 & 6.73 & 18.05 & 10.83 \\
\hline \multirow[t]{3}{*}{$\mathrm{b}_{\mathrm{z}}$} & $\mathrm{x}<100 \mathrm{~m}$ & 0.936 & 0.922 & 0.905 & 0.881 & 0.871 & 0.814 & 0.814 \\
\hline & $100 \mathrm{~m}<\mathrm{x}<1000 \mathrm{~m}$ & 1.941 & 1.149 & 0.911 & 0.725 & 0.678 & 0.74 & 0.74 \\
\hline & $1000 \mathrm{~m}<\mathrm{x}$ & 2.094 & 1.098 & 0.911 & 0.516 & 0.305 & 0.18 & 0.18 \\
\hline \multirow[t]{3}{*}{$\mathrm{C}_{\mathrm{z}}$} & $\mathrm{x}<100 \mathrm{~m}$ & 0.0 & 0.0 & 0.0 & 0.0 & 0.0 & 0.0 & 0.0 \\
\hline & $100 \mathrm{~m}<\mathrm{x}<1000 \mathrm{~m}$ & 9.27 & 3.3 & 0.0 & -1.7 & -1.3 & -0.35 & -0.21 \\
\hline & $1000 \mathrm{~m}<\mathrm{x}$ & -9.6 & 2.0 & 0.0 & -13.0 & -34.0 & -48.6 & -29.2 \\
\hline
\end{tabular}

\subsection{Deposition}

RATCHET2 calculates deposition for iodine and particles using the dry and wet deposition models used in MESORAD (Scherpelz et al. 1986; Ramsdell et al. 1988) and RASCAL (McGuire et al. 2003). The activity deposited each time step is the product of the total deposition rate and the time-step duration. At any time, the surface contamination (activity $/ \mathrm{m}^{2}$ ) is the sum of the activity deposited in the current time step plus previously deposited activity.

The dry deposition rate is calculated using a constant deposition velocity of $0.003 \mathrm{~m} / \mathrm{s}(0.3 \mathrm{~cm} / \mathrm{s})$. This deposition velocity is used because data summarized by Sehmel (1984) indicate that it is a reasonable value for iodine assuming that about one-third of the iodine in the atmosphere is associated with particles, another one-third is in the from of reactive gases (e.g., $\mathrm{I}_{2}$ or $\mathrm{HI}$ ) and the remaining onethird is in the form of nonreactive gases (e.g., $\mathrm{CH}_{3} \mathrm{I}$ ). A deposition velocity of $0.003 \mathrm{~m} / \mathrm{s}$ is slightly high for $1 \mu \mathrm{m}$ particles. The dry deposition rate is given by

$$
\omega_{\mathrm{d}}^{\prime}=-\mathrm{v}_{\mathrm{d}} \chi
$$

where $\quad \omega_{\mathrm{d}}^{\prime}=$ the deposition rate in $\left(\right.$ activity $\left./ \mathrm{m}^{2}\right) / \mathrm{s}$

$\mathrm{v}_{\mathrm{d}}=$ the dry deposition velocity

The wet deposition rate is calculated using a washout model. In the washout model, the wet deposition rate is

$$
\omega_{\mathrm{w}}^{\prime}=-\lambda \int_{\mathrm{p}}^{\infty} \chi \mathrm{dz}
$$


where $\lambda_{\mathrm{p}}$ is a washout coefficient that is a function of the precipitation type. The washout coefficients are listed in Table 4.2. These coefficients are based on analyses of experimental data by Engelmann (1968). The units for the washout coefficients are converted to $\mathrm{s}^{-1}$ for use in the model. Hanna et al. (1982) and Slinn (1984) point out that the washout model is appropriate only for monodisperse aerosols and highly reactive gases.

The total deposition rate at any point is the sum of the dry and wet deposition rates at that point. The total deposition rate is a function of position only because the concentration in the plume is a function of position. The total deposition rate is a function of position because the concentration varies in space and meteorological conditions may vary in space. The total deposition rate is a function of time at a point because both the concentration and precipitation may change with time.

RATCHET2 calculates and stores deposition by radionuclide for all radionuclides except noble gases. Noble gases are assumed not to deposit.

Table 4.2. Wash-out Coefficients ${ }^{(a)}$

\begin{tabular}{||l|c||}
\hline \multicolumn{1}{|c||}{ Precipitation Type } & $\begin{array}{c}\text { Wash-out } \\
\text { Coefficient }\left(\mathrm{h}^{-1}\right)\end{array}$ \\
\hline \hline 1 (light rain) & 0.79 \\
\hline 2 (moderate rain) & 2.2 \\
\hline 3 (heavy rain) & 4.0 \\
\hline 4 (light snow) & 0.36 \\
\hline 5 (moderate snow) & 1.2 \\
\hline 6 (heavy snow) & 2.3 \\
\hline (a) Source - Engelmann 1968. \\
\hline
\end{tabular}

\subsection{Depletion}

RATCHET2 maintains a mass balance. Material deposited on the surface by wet and dry deposition is removed from the puff by decreasing the total mass of the puff. The approach used is a variation of the source-depletion model described in Hanna et al. (1982). The mass removed from each puff is determined by analytical integration of the deposition flux over the area of the puff and the computational interval. During periods of precipitation, the additional rate of mass loss from a puff by washout of particles is determined by integrating the washout rate over the area covered by the puff, which is equal to the product of the mass in the puff and the washout coefficient. RATCHET2 computes depletion at the end of each time step.

\subsection{Meteorological Data}

The following information is needed for each meteorological station: 
- A station identification. The station identification can be any 10 letter character; the release site identification (ID) is appropriate for the first station in the station list; Federal Aviation Administration (FAA) or International Civil Aviation Organization (ICAO) location indicators are appropriate for national weather service or other stations that have them.

- The latitude (positive north of the equator and negative south of the equator) and longitude (positive east of the prime meridian and negative west of the prime meridian) of the station in decimal degrees.

- The elevation of the station (m). The elevation should be the height of the station above mean sea level.

- The surface roughness for the station (m). Meteorological texts such as Panofsky and Dutton (1984) and Stull (1988) provide guidance on estimating surface roughness. If no other information is available, a surface roughness of $0.2 \mathrm{~m}$ may be used.

- The height at which the wind measurements are made (m). The instrument height should be height above ground level.

Station meteorological data are entered for specific dates and times. The data may be actual observations (measurements) or they may be taken from meteorological forecasts. If available, the following data should be entered for each station:

- Surface-level wind direction and speed

- Estimated atmospheric stability

- Precipitation class

- Estimated mixing height

All of these data are used in the transport, diffusion, and deposition calculations. In addition, the following data should be entered for the first station (center of the grid):

- Ambient air temperature

- Pressure (station)

- Humidity measurement (dew point temperature, relatively humidity, or wet bulb temperature) The air temperature is used in plume rise calculations. 


\subsection{Calculating Spatially Varying Meteorological Conditions}

RATCHET2 takes into account both spatial and temporal variations in the atmospheric conditions. The following subsections describe the preparation of the fields from the station data.

Winds. RATCHET2 uses wind fields to calculate movement of puffs. These are fields of $U$ (eastwest) and V (north-south) components of the wind vector. The wind fields are created from station wind data using a $1 / r^{2}$ interpolation scheme, where $r$ is the distance from the grid point to the station. This interpolation scheme, which was used in earlier NRC codes such as MESOI (Ramsdell et al. 1983) and MESORAD (Scherpelz et al. 1986; Ramsdell et al. 1988), is common in spatial interpolation of the wind fields (Hanna et al. 1982).

Adjustment of Wind Fields for Topography. If the meteorological stations reporting data are well placed with respect to major topographic features, the wind fields developed by interpolation will give reasonable puff trajectories. However, with one meteorological station or a small number of stations, the wind fields may not properly reflect the effects of topography.

Stability and Precipitation. The stability class and precipitation fields (precipitation class and precipitation rate) are based on data for the closest meteorological station. Fields created in this manner include stability class, inverse Monin-Obukhov length, precipitation class, and precipitation rate. This procedure avoids averaging that would minimize the effects of extreme stability or instability. It also provides maximum detail in treating isolated precipitation events.

Mixing Height. Estimates of station mixing height are not considered particularly reliable. Therefore, the spatial variation of the mixing height is modeled using two steps. The initial step is to create a mixing height field using the mixing height for the closest station for each point in the field. If there is only one station the process is terminated after this step. The second step is taken when there are two or more stations. In this step, the mixing height at each point in the field is replaced by an average of the initial mixing height and the mixing heights at 24 surrounding points. This second step smooths the mixing height field.

\subsection{Data Requirements}

The files used in the Atmospheric Transport Module are listed in Table 4.3. The individual components of each type of file are discussed in the following subsections.

Table 4.3. Atmospheric Transport Module Files

\begin{tabular}{|l|l|l||}
\hline \multicolumn{1}{|c|}{ File } & \multicolumn{1}{|c|}{ Contents } & \multicolumn{1}{c||}{ Notes } \\
\hline \hline met.file & $\begin{array}{l}\text { File containing one year of Hanford } \\
\text { meteorological data }\end{array}$ & $\begin{array}{l}\text { Data file created by RATCHET2 user - } \\
\text { used for all simulations }\end{array}$ \\
\hline station.file & $\begin{array}{l}\text { File containing meteorological station } \\
\text { data }\end{array}$ & $\begin{array}{l}\text { Data file created by RATCHET2 user - } \\
\text { used for all simulations }\end{array}$ \\
\hline sfc_roughness.file & $\begin{array}{l}\text { File containing surface roughness } \\
\text { data }\end{array}$ & $\begin{array}{l}\text { Data file created by RATCHET2 user - } \\
\text { used for all simulations }\end{array}$ \\
\hline
\end{tabular}


Meteorological Files. The meteorological data include hourly measurements of:

- Surface-level wind direction and speed

- Estimated atmospheric stability

- Precipitation class

- Estimated mixing height

All of these data are used in the transport, diffusion, and deposition calculations. In addition, the following data are entered for the first station:

- Ambient air temperature

- Pressure (station)

- Humidity measurement (dew point temperature, relatively humidity, or wet bulb temperature)

All of these data were retrieved from the database at the Hanford Meteorological Station. Data were assembled from the database of the Hanford Meteorological Station and the surrounding grid of the Hanford reporting network for the years 1983 through 2002. These hourly data were formatted for the RACHET2 input requirements, and the completeness and acceptability of each year's data file was tested and verified.

Station Files. The locations of the meteorological data sources, and their dates of operation are listed in Table 4.4. In Table 4.4, the station at Wahluke moved to Beverly in 1991 and the station at Sage moved to the 200 West Area Plutonium Finishing Plant in 1992. The data in this table is essentially that of the station file.

Surface Roughness. The surface roughness length is associated with small-scale topographic features. It arises as a constant of integration in the derivation of the wind profile equations and is used in several boundary-layer relationships. Texts on atmospheric diffusion, air pollution and boundary-layer meteorology (Panofsky and Dutton 1984; Stull 1988) contain tables that give approximate relationships between surface roughness and land use, vegetation type, and topographic roughness. For SAC Rev. 1, a data file was adapted from the HEDR application. 
Table 4.4. Details of Meteorological Stations Supplied to the Station File

\begin{tabular}{|c|c|c|c|c|c|c|}
\hline $\begin{array}{l}\text { Station } \\
\text { Number }\end{array}$ & Site Name & $\begin{array}{c}\text { Station } \\
\text { Code }\end{array}$ & Latitude & Longitude & Height & Period of Operation \\
\hline 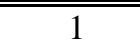 & Hanford Meteorology Station & hms & 40.563 & 119.599 & 15.2 & 01/82 - present \\
\hline 2 & FFTF & $\mathrm{fftf}$ & 46.43 & 119.36 & 9.1 & 01/82 - present \\
\hline 3 & 300 Area & $300 a$ & 46.364 & 119.2856 & 9.1 & $01 / 82$ - present \\
\hline 4 & 100-N Area & $100 n$ & 46.689 & 119.551 & 9.1 & $01 / 82$ - present \\
\hline 5 & Prosser Barricade & Prosser & 46.392 & 119.412 & 9.1 & $01 / 82$ - present \\
\hline 6 & EOC & eoc & 46.392 & 119.537 & 9.1 & $01 / 82$ - present \\
\hline 7 & Army Loop Road & army & 46.489 & 119.551 & 9.1 & $01 / 82$ - present \\
\hline 8 & Rattlesnake Springs & rspg & 46.506 & 119.7 & 9.1 & $01 / 82$ - present \\
\hline 9 & Edna rail siding & edna & 46.587 & 119.397 & 9.1 & $01 / 82$ - present \\
\hline 10 & 200 East Area & $200 \mathrm{e}$ & 46.556 & 119.521 & 9.1 & $01 / 82$ - present \\
\hline 11 & 200 West Area & $200 w$ & 46.543 & 119.663 & 9.1 & $01 / 82$ - present \\
\hline 12 & Beverly & beverly & 46.752 & 119.944 & 9.1 & $\begin{array}{l}\text { Wahluke thru 7/91, } \\
\text { Beverly 8/91 - present }\end{array}$ \\
\hline 13 & Yakima Barricade & yak & 46.578 & 119.726 & 9.1 & $01 / 82$ - present \\
\hline 14 & Wye Barricade & wyeb & 46.482 & 119.391 & 9.1 & $01 / 82$ - present \\
\hline 15 & Energy Northwest & wnp2 & 46.47 & 119.345 & 9.1 & $01 / 82$ - present \\
\hline 16 & Franklin County & franklin & 46.417 & 119.238 & 9.1 & $01 / 82$ - present \\
\hline 17 & Ringold & ringold & 46.545 & 119.238 & 9.1 & $01 / 82$ - present \\
\hline 18 & Richland Airport & richland a & 46.301 & 119.301 & 9.1 & $01 / 82$ - present \\
\hline 19 & Plutonium Finishing Plant & 200W PFP & 46.545 & 119.633 & 9.1 & \begin{tabular}{|l|} 
Sage thru 1994, \\
PFP 3/94 - present
\end{tabular} \\
\hline 20 & Tri-Cities Airport & pasco air & 46.257 & 119.114 & 9.1 & 10/87 - present \\
\hline 21 & Gable West & gable west & 46.612 & 119.558 & 9.1 & 3/86 - present \\
\hline 22 & 100-F Area & $100 f$ & 46.635 & 119.452 & 9.1 & 3/86 - present \\
\hline 23 & Vernita Bridge & vernita & 46.641 & 119.728 & 9.1 & 2/88 - present \\
\hline 24 & Benton City & benton city & 46.29 & 119.608 & 9.1 & 2/95 - present \\
\hline 25 & Vista & Vista. & 46.218 & 119.201 & 9.1 & 2/91 - present \\
\hline 26 & Roosevelt, Washington & Roosevelt & 45.744 & 120.218 & 9.1 & 9/94 - present \\
\hline 27 & 100-K Area & $100 \mathrm{k}$ & 46.657 & 119.578 & 9.1 & 3/96 - present \\
\hline 28 & HAMMER & hammer & 46.356 & 119.326 & 9.1 & 1/98 - present \\
\hline 19 & Sage & sage & 46.735 & 119.836 & 9.1 & $01 / 82-12 / 92$ \\
\hline 12 & Wahluke & wahluke & 46.656 & 119.299 & 9.1 & $01 / 82-7 / 91$ \\
\hline
\end{tabular}




\subsection{History Matching/Validation with Krypton-85 Monitoring Data}

Processing of reactor fuel is accompanied by the release of noble gas fission products, including krypton-85. The last processing of reactor fuel at Hanford occurred in the PUREX Plant in the 200 East Area intermittently from December 1983 through November 1987. Annual krypton-85 releases at Hanford for this period were reported in annual environmental reports. The total release for PUREX for the period was approximately 1.7 MCi. Krypton-85 activity released from other locations was signifycantly lower ( $\sim 7 \mathrm{kCi}$ ) than the PUREX releases. The 1984 through 1987 krypton-85 releases were chosen for use in evaluation of RATCHET2, because the PUREX Plant was the dominant source during this period and the Surface Environmental Surveillance Project measured krypton-85 concentrations at a number of locations on and near the Hanford Site. Krypton data for 1983 were not included because the releases were not distributed through-out the year. For RATCHET2 evaluation for SAC Rev 1, the releases were assumed to take place at a constant release rate from a 61-m stack in a nominal flow of about $9.4 \mathrm{~m}^{3} / \mathrm{s}$ at a temperature of about $25^{\circ} \mathrm{C}$.

The Surface Environmental Surveillance Project collected air samples at a number of locations on site, near the boundary of the Hanford site, and off site during the period of interest. Twelve of the locations were within, or sufficiently close to, the RATCHET2 domain to provide measured concentration for comparison with model estimates. Of these locations, three were within $3 \mathrm{~km}$ of the PUREX stack, five were between 18 and $25 \mathrm{~km}$ from the stack, and the remaining four locations were between 38 and $45 \mathrm{~km}$ from the stack. One location at $25 \mathrm{~km}$ occasionally had two monitors running simultaneously. The air samples typically covered 28 day periods, with a range from 14 days to 42 days. Average concentrations for each period were determined by counting the activity in the samples; typical counting errors were 10 to 15 percent. However, the monitoring was not continuous at any location. Consequently, annual average concentrations were estimated using a weighted average of the available data for comparison with concentrations predicted by RATCHET2. Ultimately, there were 41 usable estimates of annual concentrations at the 12 locations.

RATCHET2 generally predicts the annual concentrations well $\left(r^{2}=0.81\right)$, although the model has a bias to slightly over-predict concentrations (geometric mean ratio between the predicted and measured concentrations $=1.26$ with a geometric standard deviation of 1.7). Model errors were greatest for the 3 monitoring locations near PUREX, where the concentrations and concentration gradients are highest. Farther from PUREX, RATCHET2 predicted 28 of 33 concentrations within a factor of 2 and all 33 concentrations within a factor of 3 . Neither the krypton-85 releases nor the monitoring were continuous. Thus, estimation of annual concentrations from the monitoring data is a source of uncertainty. However, it does not appear to have contributed to the differences between concentrations predicted by RATCHET2 and those estimated from monitoring data in a systematic manner. 


\subsection{References}

Athey GF, AL Sjoreen, JV Ramsdell Jr., and TJ McKenna. 1993. RASCAL Version 2.0 User's Guide. Vol. 1, Rev. 1 NUREG/CR-5247, U.S. Nuclear Regulatory Commission.

Bander TJ. 1982. PAVAN: An Atmospheric Dispersion Program for Evaluating Design Basis Accidental Releases for Radioactive Materials from Nuclear Power Stations. NUREG/CR-2858, U.S. Nuclear Regulatory Commission.

Csanady GT. 1973. Turbulent Diffusion in the Environment. D. Reidel, Boston, Massachusetts.

DOE M 435.1. 1999. Radioactive Waste Management. U.S. Department of Energy, Washington, D.C. Available on the Internet at http://www.hanford.gov/wastemgt/doe/psg/pdf/doeo435.1.pdf

DOE Order 435.1-1. 1999. Radioactive Waste Management Manual. U.S. Department of Energy, Washington, D.C. Available on the Internet at http://www.directives.doe.gov/pdfs/doe/doetext/neword/435/m4351-1c1.html

Draxler RR. 1984. "Diffusion and Transport Experiments.” Atmospheric Science and Power Production. D. Randerson (ed.), DOE/TIC-27601, U.S. Department of Energy.

Eimutis EC and MG Konicek. 1972. "Derivations of Continuous Functions for the Lateral and Vertical Atmospheric Dispersion Coefficients.” Atmospheric Environment 6:859-63.

Engelmann RJ. 1968. “Calculation of Precipitation Scavenging.” Meteorology and Atomic Energy 1968. Ed. D. Slade, TID-24190, U.S. Atomic Energy Agency.

Gifford FA. 1976. “Turbulent Diffusion-Typing Schemes: A Review.” Nuclear Safety, 17 No. 1: 68-86.

Hanna SR, GA Briggs, and RP Hosker. 1982. Handbook on Atmospheric Diffusion. DOE/TIC-11223, U.S. Department of Energy.

Kincaid CT, MP Bergeron, CR Cole, MD Freshley, NL Hassig, VG Johnson, DI Kaplan, RJ Serne, GP Streile, DL Strenge, PD Thorne, LW Vail, GA Whyatt, and SK Wurstner. 1998. Composite Analysis for Low-Level Waste Disposal in the 200 Area Plateau of the Hanford Site. PNNL-11800, Pacific Northwest National Laboratory, Richland, Washington.

Kincaid, CT, RW Bryce and JW Buck. 2004. Technical Scope and Approach for the 2004 Composite Analysis of Low-Level Waste Disposal at the Hanford Site. PNNL-14372 DRAFT, Pacific Northwest National Laboratory, Richland, Washington.

Martin DO and JA Tikvart. 1968. "A General Atmospheric Diffusion Model for Estimating the Effects on Air Quality of One or More Source.” $61^{\text {st }}$ Annual Meeting of the Air Pollution Control Association for NAPCA, St. Paul, Minnesota. 
McGuire SA, GF Athey, JV Ramsdell Jr., AL Sjoreen, TJ McKenna, and C Fosmire. 2003. RASCAL 3: Description of Models and Methods, NUREG-1741 Rev. 1. U.S. Nuclear Regulatory Commission.

Panofsky HA and JA Dutton. 1984. Atmospheric Turbulence. J. Wiley \& Sons, New York.

Press WH, BP Flannery, SA Teukolsky, and WT Vetterling. 1986. Numerical Recipes: the Art of Scientific Computing. Cambridge University Press, Cambridge, United Kingdom.

Ramsdell Jr. JV, GF Athey, and CS Glantz. 1983. MESOI Version 2.0: An Interactive Mesoscale Lagrangian Puff Dispersion Model With Deposition and Decay. NUREG/CR-3344, U.S. Nuclear Regulatory Commission.

Ramsdell Jr. JV, GF Athey, TJ Bander, and RI Scherpelz. 1988. The MESORAD Dose Assessment Model, Volume 2: Computer Code. Vol. 2, NUREG/CR-4000, U.S. Nuclear Regulatory Commission.

Ramsdell Jr. JV, CA Simonen, and KW Burk. 1994. Regional Atmospheric Transport Code for Hanford Emission Tracking (RATCHET). PNWD-2224 HEDR, Battelle, Pacific Northwest Laboratories, Richland, Washington.

Randerson D. 1984. Atmospheric Science and Power Production. DOE/TIC-27601, U.S. Department of Energy.

Sagendorf JF, JT Goll, and WF Sandusky. 1982. XOQDOQ: Computer Program for the Meteorological Evaluation of Routine Effluent Releases at Nuclear Power Stations. NUREG/CR-4380, U.S. Nuclear Regulatory Commission.

Scherpelz RI, TJ Bander, GF Athey, and JF Ramsdell II. 1986. The Mesorad Dose Assessment Model. Vol. 1., NUREG/CR-4000, U.S. Nuclear Regulatory Commission.

Sehmel GA. 1984. “Deposition and Resuspension.” Atmospheric Science and Power Production. D. Randerson (ed.), DOE/TIC-27601, U.S. Department of Energy.

Seinfeld JH. 1986. Atmospheric Chemistry and Physics of Air Pollution. John Wiley \& Sons, New York.

Stull RB. 1988. An Introduction to Boundary Layer Meteorology. Kluwer Academic Publishers, Dordrecht, Netherlands.

Slade DH. 1968. Meteorology and Atomic Energy 1968. TID-24190, U.S. Atomic Energy Agency.

Slinn WGN. 1984. "Precipitation Scavenging.” Atmospheric Science and Power Production. D. Randerson (ed.), DOE/TIC-27601, U.S. Department of Energy.

Tadmor J and Y Gur. 1969. “Analytical Expressions for Vertical and Lateral Dispersion Coefficients in Atmospheric Diffusion.” Atmospheric Environment 3:688-98. 


\section{Distribution}

No. of

Copies

\section{ONSITE}

2 DOE Office of River Protection

R. M. Yasek

R. W. Lober

9 DOE Richland Operations Office

B. L. Charboneau A6-33

B. L. Foley A6-38

J. P. Hanson A5-13

R. D. Hildebrand A6-38

J. G. Morse A6-38

K. M. Thompson A6-38

S. H. Wisness A3-04

DOE Public Reading Room (2) H2-53

5 Bechtel Hanford Inc.

P. G. Doctor

H9-01

K. R. Fecht

K. A. Gano

H9-04

H6-60

J. K. Linville

$\mathrm{H} 0-23$

H0-23

9 CH2M HILL Hanford Group, Inc.
F. J. Anderson
A. J. Knepp
M. N. Jarayssi
F. M. Mann
W. J. McMahon
C. W. Miller
D. A. Myers
C. D. Wittreich
M. I. Wood

E6-35

H6-03

H6-03

E6-35

E6-35

H6-62

E6-35

H6-62

H8-44

\section{Fluor Federal Services}

R. Khaleel

R. J. Puigh

E6-17

E6-17
No. of

Copies

8 Fluor Hanford, Inc.

J. V. Borghese E6-35

F. M. Coony E6-35

B. H. Ford E6-35

T. W. Fogwell E6-35

R. Jackson E6-35

V. J. Rohay E6-35

L. C. Swanson E6-35

M. E. Todd-Robertson E6-35

Stoller

$\begin{array}{ll}\text { R. G. McCain B2-62 } & \text { B }\end{array}$

47 Pacific Northwest National Laboratory

R. L. Aaberg K3-54

C. Arimescu K6-04

M. P. Bergeron K9-36

B. N. Bjornstad K6-81

R. W. Bryce E6-35

A. L. Bunn K6-85

K. J. Cantrell K6-81

Y. J. Chien K6-81

R. L. Dirkes K6-75

J. L. Downs K6-85

D. W. Engle K5-12

P. W. Eslinger K6-04

M. J. Fayer K9-33

E. J. Freeman K9-36

M. D. Freshley K9-33

G. W. Gee K9-33

T. J. Gilmore K6-81

D. G. Horton K6-81

C. T. Kincaid K9-33

G. V. Last (5) K6-81

C. A. LoPresti K5-12

W. J. Martin K6-81

T. B. Miley K6-04

C. J. Murray K6-81

B. A. Napier K3-54

W. E. Nichols K9-33 
PNNL-14599, Rev. 0

No. of

Copies

G. W. Patton

J. V. Ramsdell, Jr.

S. P. Reidel

M. C. Richmond

R. G. Riley

M. L. Rockhold

R. J. Serne

D. L. Strenge
No. of

Copies

M. B. Triplett

K6-04

P. D. Thorne

K9-33

A. L. Ward

K9-33

M. D. White

K9-36

M. D. Williams

K9-36

S. K. Wurstner

K9-36

S. B. Yabusaki

K9-36

Hanford Technical Library (2)

H2-53 